\title{
From Financialization to Low and Non-profit: Emerging Media Alternatives for Freedom ${ }^{1}$
}

\author{
Núria Almiron-Roig
}

\author{
Department of Communication, Pompeu Fabra University, Barcelona SPAIN \\ nuria.almiron@upf.edu
}

\begin{abstract}
In the midst of what is probably the worst economic and financial crisis the capitalist world has ever experienced, professional journalistic structures and news organizations are disintegrating. While mainstream current economic and media gurus - and the whole media executive class around the globe - are clamouring for a business model change that allows them to go on making lots of money, many voices have been raised in unison to ask for a true radical change: the public interest should be the first goal, and not money. This paper presents the outcome of a research project on non-profit alternatives currently under debate, the aim of which is to help journalism survive.
\end{abstract}

Keywords: financialization, non-profit journalism, public interest and democracy

Corporatization and financialization trends have had a tremendous impact on media companies and journalism in recent decades. In this context, any attempt to really pursue professional independence, democratic values, true investigative reporting and quality-control routines have been persistently hindered by advertisers, the market and financial capital interests.

At the same time, the leveraging fever of the preceding years (that is, the strategies of corporate growth based on financial debt) produced a giant-with-feet-of-clay effect on the media industry (as well as on most sectors of the economy). Instead of being financially reinforced, the media industry became a business built on sand. In 2009, due to the global economic crisis (and its consequent advertising crisis), media companies everywhere were seeing their debt turned into junk status by rating agencies, as revenues plummeted and stocks sank. That made it impossible to refinance the only solution a capitalist economy offers besides layoffs and cost cuts - and made the extent of the media industry's accounting instability vividly clear ${ }^{2}$. The dramatic spiral of bankruptcies in media companies that this instability generated is well known to all of us.

During this journey, instead of advances in the traditional division that for many should be a must for achieving quality in journalism (i.e., protecting the autonomy of the newsroom as it faces outside pressures), recent decades have seen the opposite trend: an even greater narrowing of the gap between the journalistic company and advertisers, bankers, financiers, and industrial businesspeople. Nowadays, a large number of representatives of economic-financial capitalism are sitting on most of the main media boards of directors. The consequences of this have been denounced by many as, to say the least, unhealthy.

In response to the effects of corporate media and the financialization ${ }^{3}$ of business, debt, ownership, corporate goals and boards, many have called for a profound and radical reform of the media system as the only chance journalism has to ever become a real, free watchdog of power. The first aim of this paper is to pick up on these alternative calls in order to distinguish them from what can be called the 'mainstream call'. This mainstream call comes from mainstream current economic

\footnotetext{
${ }^{1}$ A draft of this paper under the title "From Financialization to Freedom: Emerging Media Business Models" was presented at the IAMCR Conference 2010 Communication and Citizenship, held in Braga, Portugal, 18-22 July, 2010.

${ }^{2}$ For an excellent critical overview of the economical and financial crisis from a communication perspective, see Thompson, 2010.

3 'Corporate media' is almost synonymous with 'financialization', a system of media production, distribution, ownership, and funding of media companies that is dominated by corporations and governed by the capitalist imperatives of maximizing profits for investors, stockholders and advertisers; in the term 'financialization', the stress falls on the financial imperatives inside this logic. For an in-depth description of media financialization trends, see Almiron 2010.
} 
and media gurus - and the whole media executive class around the globe -, who are clamouring for a business model change that takes into account the transformation experienced by the media sector. However, the truth is that they are asking for more of the same.

First, some prominent digital utopians have been talking about old-fashioned industries and strategies as the main cause of the media's downfall, but the reality is that their main criticism has not been levelled against the production model (dominated by financial capitalism) but against corporate routines and professional practices inside the industry. As far as the business model is concerned, most of them have been concerned only about how to earn money online ${ }^{4}$.

Second, the same criticism can be levelled at well-known pro-market proponents with far more elaborate and intelligent discourses on markets, capital and the media than those of digital utopians. They are mainly concerned with building alternative media business models that ultimately adhere to the very traditional core concept of capitalist business-as-usual. Although this is apparently a quantum leap in thinking, they keep regarding the media merely in terms of value for money, products and services, users and uses, consumption and added value (see, for instance Picard, 2010).

The diagnosis that they all present is irrefutable (patterns of consumption have changed, subscription and advertising can no longer be the main funding resources, mass audience is becoming a niche audience, etc.) but superficial. It is so because it only takes into account the impact of technology on the media system, and not the core flaws of the system itself. In not doing so, they miss what must be changed in depth. Furthermore, their proposals (mainly looking at alternative commercial activities that can subsidize the provision of news) only have an impact on the surface; they do not alter the model, but only the tools used to make money.

For many others, however, it is undeniable that if capitalism fails, the solution is not more capitalism. Therefore, they suggest that we should not seek to replace old business models with new business models, but with new models devoid of business if necessary - or at least with a notion of business far more linked to social justice, solidarity, empathy and sustainability than the current capitalist business approach.

Faced with this fact, some have started talking about the definitive dismantling of journalism or, that is, about its definitive collapse as a potential tool to scrutinize private and public affairs in democracies if the business-approach dominance persists. Thus, while the business class and their gurus keep on looking for ways to make money with journalism (or through journalism), an increasing number of scholars, journalists and social activists all over the world - and even some political decision makers - are raising their voices, calling for efforts to put capitalist profit aside and to give priority to democracy. In the U.S. in particular, the demand to save journalism has risen to unexpected heights, but in Europe and Latin America, people have been working for quite some time in cooperative ways to raise their voices against using the media for profit (or only for profit), with very recent interesting political initiatives in some Latin-American nations.

Their call is, in some cases, merely a step towards change, while, in others, it is a clamour for a complete change in the media sector. But they all share a main objective: to foster the potential democratic values of journalism and protect them from non-democratic influences. The salient fact is that for the first time these are not isolated proposals made by a few voices, but a chorus of ideas by proponents increasingly singing from the same hymn sheet while coming from very different places. They do not share identical principles or the same level of social impact. But they all are calling for that change in the true core of the so-called 'media business'.

In this context, the second aim of this paper is to provide a sort of classification of the main existing alternative proposals in the U.S., Latin America and Europe, along with a description and current examples. Thus, this paper is a descriptive one, although some questions for debate are introduced in the final discussion section. The ultimate goal of this research project has been to provide a view of what can be considered the most significant movement to date against the corporatization

\footnotetext{
${ }^{4}$ Digital utopians' proposals started well before the media's current financial crisis. A critique on their approach has been provided by, among others, Lacroix \& Tremblay, 1997; McChesney et al, 1998; Garnham, 2000; Reig, 2001; Bustamante, 2003; Mosco, 2005; and Almiron \& Jarque, 2008.
} 
and financialization of the media and journalism (and the most important activist movement as well, in the case of some countries). It is not irrelevant to underscore that for many of their promoters these are not mere alternatives; they are the only chance that journalism has to ever become a real tool for improving democracies rather than a mere instrument for making money, be it directly (through profits) or indirectly (through influence).

In the following sections, previous research and a theoretical starting point shared by the chosen proposals is provided (Section 1 and 2), as well as a classification of the main types of proposal (Section 3) and the main ideas for funding (Section 4), along with the current U.S. and LatinAmerican initiatives (Section 5). Some discussion is provided at the end.

\section{Previous Research and Questions}

Very little research has been conducted on media business models devoid of a managerial and financial/for-profit point of view. On the contrary, almost all research on the non-profit media field is conducted in relation to community, local or alternative media (the 'nanomedia' defined by Downing, 2010). The reason for this is simple, the research reflects reality: private non-profit media have been mainly regarded as a marginal issue everywhere.

In 2008, Robert G. Picard and Aldo van Weezel explored the consequences of different forms of U.S. newspaper ownership (namely: private, publicly traded, foundation, non-profit and employee). They concluded that, although forms of non-profit ownership can provide some advantages in terms of financial pressures for profit, this is not necessarily the case. Furthermore, those non-profit forms (foundation, charitable or non-profit ownership) also create or expose newspapers to other constraints and issues and do not guarantee journalistic excellence according to some researchers (Picard \& Weezel, 2008).

In the same work, Picard and Weezel recognized, however, that research on non-profit ownership is very scarce and that they studied the issue by focusing exclusively on companies' financial and managerial performance. But, of course, this focus does not guarantee excellence in journalism. In their study, the fact that the ability to acquire and self generate capital, the profit motive and the value-growth incentive are all low in non-profit ownership is regarded as a disadvantage. This is quite logical considering what the researchers were concerned with - corporate performance -, but this does not, of course, automatically prevent media corporations from achieving quality in journalism. Actually, for many, quality and excellence in journalism is something far more linked to professional and human values than to business performance (Kovach \& Rosenstiel, 2001).

Nevertheless, the article by Picard and Weezel is a very helpful piece of work that concludes that there is no perfect form of ownership - at least as far as newspapers are concerned. This inevitably leads us to question how we should tackle social organization: Should we look for perfect forms of organization or rather for the least harmful ones? Should we consider what is harmful in terms of private/individual or public/social interests? Should we define public interest in relation to business performance? And should we wait for the perfect piece of research to decide what is the least harmful form of using the media in democracies (and hope that some sort of journalism is left by then), or rather should we reorganize the whole industry as soon as possible in keeping with the values and ethics of global solidarity, empathy and sustainability? The proposals introduced in this paper can be regarded as a preliminary answer to these questions.

\section{Common Framework of the Proposals}

The proposals gathered for this paper are diverse and varied, but together they add up to a triple, strong, deep conviction that can be considered a common starting point or framework for all of them:

i) That journalism is a democratic craft par excellence, and corporatization and financialization of the media does not allow this potential to be developed. 
ii) That a real alternative to the market option is possible regarding the use of the media in democracies.

iii) And that the current scenario is the worst ever and thus there cannot be further delays in terms of guaranteeing the right conditions for a non-market-driven scenario for journalism.

\subsection{Journalism as a Democratic Craft}

The first common trait shared by the proposals gathered here is that journalism - exercised through print press, broadcasting and the Internet - is regarded as a potentially democratic craft. This does not mean that the promoters of these proposals are naïve supporters of an idealised view of journalism; rather, they are ferocious critics of wasting the media's potential to improve democracy. Actually, most of the promoters of the proposals presented here would probably agree with the notion that journalism has historically been in a permanent state of crisis: a historical crisis, as it has had to confront a set of ideal values with the historical construction of a profession and an industry constantly subject to the instrumentalization of dominant classes, whether religious, political or economic (as brilliantly described by Vázquez Montalbán, 2000). But the recurrent failure of journalism as a democratic craft does not prevent proponents from clamouring for its potentially democratic use.

The belief that professional journalism can serve democratic values for good, and that it can have democratic duties and goals assigned to it, is a notion strongly rooted in the modern AngloSaxon journalistic tradition, although this is something that has been taken on by non-Anglo-Saxon countries too.

In the U.S., although in opposition, John Dewey (1859-1952) and Walter Lippmann's (18891974) role of journalism in democracy can be considered to be at the root of this tradition. Also in the U.S., but more recently, G. Stuart Adam and Roy Peter Clark have argued that journalism "is the democratic craft par excellence" and that it is "uniquely born in a system of rights that allows for freedom of expression and [...] that it operates in a citizen's culture in which practical truth and verifiable fact are essential goods". These authors believe journalists have a social contract with their fellow citizens to bring a real world into a view and that "the richer the portrait, the richer the possibilities of democratic life" (Adam \& Clark, 2006: xi). Paradoxically, the U.S. is one of the Western democracies where journalism has grown more narrowly in connection with capitalism, but it is also where voices against those capitalist practices regarding journalism have been raised in the most organized manner.

Besides the U.S. influence, a prominent source linking journalistic practices and the quality of democracies during the second half of $20^{\text {th }}$ Century can be found in the UNESCO scenario of the 1960s and 70s, ending with the MacBride Report (1980). The Report's influence in Latin America and European Union countries is still visible in the rhetoric and goals of current European and Latin-American communication policies (Consell de l'Audiovisual de Catalunya, 2005). Actually, most of the media policies adopted in Western democracies are based on, or at least justified by, the notion that journalistic values - such as providing transparency, showing diversity and creating knowledge - should be encouraged and protected if we want to have a real chance of building strong democracies.

Up to now, the traditional attempts of preventing market forces from overwhelming democratic values in the media sector have been based on regulations for the protection of pluralism. Restrictively regulating the commercial market (or external pluralism, by limiting ownership, licensing and audience/population reach) and, in some cases, regulating internal pluralism as well (mainly content), have become the most widely used tools in modern democracies to counteract the shortcomings and deviations from social responsibility of commercial corporate media. In Europe, public broadcasting systems have also been a common area of regular legislative changes - in order to depoliticise them in Mediterranean countries, and to ensure high levels of quality and social representativeness in northern Europe, for instance. In all cases, the goal has been the same: restrictively regulating in order to protect the democratic values of the media in commercial or public sectors. 
It is a well-known fact that regulation against market concentration has progressively been relaxed over the last decade for a variety of reasons. First, there have been commercial sector calls for more free market and less state intervention, in the belief that this was a way of maximizing profits. Second, we cannot, of course, ignore the important ideological task carried out globally by conservative think tanks aimed at preserving capitalism as it is (radically unfair for many but very lucrative for some). Finally, major economic and financial downturns (which cyclically show up in capitalism) produce the ideal emergency scenario to push politicians towards any kind of shortterm policies that can provisionally alleviate national corporate troubles, even at the expense of potentially negative long-term effects on pluralism and democracy.

The major contradictions occasioned by the above-mentioned trends have been widely noted by many stakeholders, including those who not only demand less state intervention and more free market when the economic situation yields individual profits in large quantities, but also ask for government/collective aid when the scenario turns down and produces losses (putting into practice the old saying "privatizing profits and socializing losses"). Nevertheless, and in spite of this inconsistency, free market proponents are right when they denounce the ineffectiveness of pluralism regulation to prevent concentration in media markets, since trends towards concentration have continued over the last decade in spite of all the regulations put in place ${ }^{5}$.

Regarding the latter, there are two explanations according to the most common arguments. First, concentration may have increased in spite of regulation because the law has not been restrictive enough or fully applied. Second, concentration may have increased in spite of regulation because capitalism tends naturally towards concentration and no regulation can prevent this. In this latter view, a change not only in policies but also in the actors themselves is required in order to get the most from our media system. This argument includes both the free market proponents - who argue that regulation impedes the free market from blossoming, and that this is the cause of all our problems - and the non-market or not-only-with-market proponents - who argue that a real change is required, beginning with policies that remove the dominance of the market and ending with a social reformation. Both views usually incorporate the democratic rhetoric into their claims; however, while the former are stressing business freedom embedded in the notion of liberal democracy, the latter are stressing a more humanistic and wider notion of freedom.

\subsection{Getting Rid of Casino Capitalism}

The second and third traits shared by the proposals gathered here are interconnected. They have to do with the need to look for different alternatives to the market option and financial capitalism, since they have both proven to be so faulty and inefficient - not only in terms of using journalism as a democratic craft, but also of taking a merely business-oriented approach. This claim can be rooted in the political economists' and political economy of communication's claims, as well as in the recent empirical experience.

Since financial markets, and subsequently the economy, started to collapse in $2007^{6}$, the permanent crisis in which journalism was immersed has led to one of the worst scenarios in recent decades. Suddenly, the trend towards concentration that had allowed a handful of huge media conglomerates to own a majority of the market turned out to have no solidity at all - regardless of the impressive turnovers, profits, financial assets, quotes and facilities they had been boasting about just a few months earlier. Throughout 2009 and 2010, thousands of jobs were lost around the globe, many foreign news bureaus closed, hundreds of companies went bankrupt, many subsidiaries were sold and pluralism suffered yet another defeat as concentration increased in the wake of such consequences. Nevertheless, as I have explored at more length elsewhere (Almiron, 2010), the financial and economic turbulence starting in 2007 was by no means the cause of the

\footnotetext{
${ }^{5}$ Among the most recent works reporting on issues related to concentration, we could mention Doyle (2007) on the European Union's inaction in the face of media concentration; McChesney (2008) for the U.S. scenario; Bouquillion (2008) for an international approach; or Becerra \& Mastrini (2009) for the Latin-American case.

${ }^{6} 2008-2010$ economic crisis actually began with the subprime crisis in the U.S. in the summer of 2007 , which progressively spread to the rest of the financial markets throughout 2008 and, by 2009 , to the global economy.
} 
crisis in corporate journalism. Nor was it the Internet, ICTs or digital convergence and their new business models looming on the horizon. Nor was it the advertising slump or changing consumer patterns. Rather, financialized corporate logics have been at the true core of the dismantling of the democratic potential of journalism in recent decades.

In this scenario, the solutions adopted have been paradoxical: the criterion that pushed the gigantic and oligopolistic media sector to its pre-crisis situation (i.e., that pushed it to a critical juncture: McChesney, 2007) is the same criterion that has been applied to crisis recovery. We could say the same for the whole economy as a matter of fact. That criterion is that if revenues and profits stop coming in at the desired rate (although impossible at the expected scale and pattern), then costs must be reduced. Because corporations have been acting as if the growth ratio of revenues and profits could escalate permanently, crises have always caught them unaware. Hence, most of them needed a drastic restructuring at the onset of a crisis. That is, costs have been drastically reduced, sometimes completely (by going bankrupt).

As long as twenty years ago, Canadian-born economist John Kenneth Galbraith had already explained why this phenomenon occurs (Galbraith, 1993). In A Short History of Financial Euphoria, Galbraith reminds us of the extreme brevity of financial memory in the history of capitalism. That is why financial disasters are quickly forgotten and the speculative episodes of financial euphoria can be repeated over and over again. The crux of the matter, according to Galbraith, is that all analyses persistently preclude any serious contemplation of the true nature of what is taking place: recurrent episodes of mass insanity.

Galbraith studied all the great speculative episodes of the last three centuries (up to the early 1990s) and discovered the recurrence of common features. Two factors especially contribute to and support every episode of euphoria: first is the extreme brevity of financial memory mentioned above, and second is the specious association of money and intelligence: "Money is the measure of capitalist achievement. The more money, the greater the achievement and the intelligence that supports it." Over and over again, the "investing public is fascinated and captured by the great financial mind. That fascination derives, in turn, from the scale of the financial operations and the feeling that, with so much money involved, the mental resources behind them cannot be less" (Galbraith, 1993, pp. 14 and 17).

But there is a third common feature that is equally as important. Galbraith's: "The world of finance hails the invention of the wheel over and over again, often in a slightly more unstable version. All financial innovation involves, in one form or another, the creation of debt secured in greater or lesser adequacy by real assets" (Galbraith, 1993, p. 19). The invention of the wheel over and over again (i.e., recurrently celebrating someone's genius in discovering and using leverage) could have had a strong opponent in the media companies if journalism had been reporting in the proper way (taking its democratic role as its primary goal). Obviously, this was not the case.

Media conglomerates have not helped to bring the recurrent wheel/leverage invention fraud out into the open. Worse still, they have actually played a crucial role in supporting speculative escalations and moods, reinforcing the notion that euphoric moments are well within the norms of successful contemporary capitalism and that the rewards of speculation can be something durable and sane. When the optimism disappears and crisis and recession emerge, they can be seen to have played a significant role in supporting the Schumpeterian notion, recalled by Galbraith, that the contraction is also normal, tolerable and even benign.

Media conglomerates, in short, have not helped combat the loss of our financial memory, and they have played a key role in building up personal success stories based on the notion that a good fortune is due to superior acumen; that wealth comes from an exceptional mental aptitude; and that if a lot of money is involved, this must be a serious and superior business. Then comes the crash, and for a while the media recognize the failure. But the cycle starts again (sometimes after a few decades, at other times after only a few years) with the same recurrent pattern: "[Every euphoric episode] is protected and sustained by the will of those who are involved, in order to justify the circumstances that are making them rich. And it is equally protected by the will to ignore, exorcise, or condemn those who express doubts" (Galbraith, 1993, p. 11). 
For Galbraith and many others, among them some proponents of the proposals introduced in this paper, media conglomerates have been among the main supporters of this will, as a consequence of taking as their primary role their commercial rather than their democratic function. Actually, media conglomerates have become key sites for the optimism that is built on the optimism that drives prices up. Media conglomerates have also become financial players and objects in speculation moods. If any lesson is to be learnt from the current crisis, it is that, once again, reality has shown that permanent growth as a way of organizing life on this planet is a fallacy and leads to collapse. The culture of permanent growth that financial capitalism has been exploiting at an unprecedented rate has recurrently shown that growing instability, inequality and pain is what we can expect at the end of the road - at least for most of us. The media system helped build that erroneous belief and yielded to it when the fallacy collapsed.

This is the framework in which we are able to contextualize the ideas introduced in the pages that follow. Although there are many differences, they all share the notion that we strongly need to remove capitalist pressure from news organizations. That is, we need to restrict or eliminate what has been the main aim of corporate media throughout the $20^{\text {th }}$ century and even today: primarily, and above all, making money. Some of the ideas propounded have acknowledged this fact openly, while in other instances this has not happened. The latter is the case mainly in the U.S., where the free market is an idea so deeply embedded in the American DNA that few dare to be seen as if they were attacking it, under penalty of being regarded as unpatriotic. But the goal at which all proponents aim is the same: removing most of the ties that link media organizations to financial capitalism and the commoditization of journalism. That means directly attacking common media conglomerate features, such as:

- Financialized media ownership, i.e. financially oriented shareholders (news media corporations owned by equity or investment firms or with large parts of their stock in the hands of institutional shareholders).

- Media companies acting according to their virtual worth or 'fictitious capital' (stock market quotes) as Marxist authors describe it, always based on expectations instead of their productive value (present and real turnover and benefits).

- Media companies growing on financial debt (highly leveraged corporations in the hands of their creditors).

- Bankers or advertisers sitting on the boards of directors of media firms (or on any sort of advisory board).

- Media companies participating in financial business activities that are openly in conflict or at odds with media responsibilities in democracies (speculative investments).

In Europe, French economist Frédéric Lordon ${ }^{7}$ has openly suggested what many are privately thinking: we must get rid of fictitious capital. In other words, there is only one way to get rid of the perverse effects of the current casino capitalism: to close down stock exchange markets. Lordon explains in a very convincing way how this can have two significant effects: first, it will stop feeding a speculative arena with such harmful consequences on the real economy; and, second, it will remove the insane idea of success related to lightning-fast enrichment, regardless of the real effort and ethical values behind it.

Lordon's work explains in very simple words how stock exchange markets no longer finance companies; indeed, he claims that companies now finance stock exchange markets. This is because return on investment (i.e., dividend payments and buybacks) exceeds real corporate investment itself. When confronted with this fact, a question arises: how in this context is it possible for financial capital invested in stock exchange markets to be growing every day? Lordon puts it simply:

\footnotetext{
${ }^{7}$ Frédéric Lordon is Research Director at Centre National de la Recherche Scientifique and a researcher at the Centre de Sociologie Européenne in France.
} 
Because of speculation. Speculative activity is the main activity of stock exchange markets nowadays. Thus, in spite of what orthodox economists and neoliberal experts tell us, stock exchange markets are not the cornerstone of modern economy, the main financial source for companies or the essential tool for start-ups. The stock exchange is simply a money factory. (Lordon, 2010). ${ }^{8}$

Nowadays, ridding media companies of casino capitalism is a must for the proponents introduced here if journalism is ever to become a real cornerstone for building a healthier democracy. Actually, this hypothesis is strongly supported at universities by scholars from the political economy of communication perspective. Several of them have shown the disastrous impact that being present on stock exchange markets and other financial arenas has had on media firms. American Philip Meyer described how newspapers were captured by Wall Street (2004). French Philippe Bouquillion, Bernard Miège and Christian Pradié depicted how stock exchange markets and financial mergers lead the global media industry to their financialized stage (Bouquillion, 2005 and 2008; Bouquillion, Miège \& Pradié, 2003). Winseck has made the case for the Canadian media industry through the rise and fall of some big Canadian media conglomerates (Winseck, 2010). The author of the present paper has also developed the concept of financialized global news media as the biggest obstacle by far for independent quality journalism as stated before. All of them consider the current situation of media financialization as an unprecedented harmful scenario as far as journalism as a democratic tool is concerned. Although differently nuanced, this belief is at the core of all the proponents' ideas for freeing journalism from the business and money-centred views introduced in the following sections.

\section{Restructuring Media Away from Money Pressures}

Democracy and capitalism seem tightly bound together, at least from a liberal point of view. But, as a matter of fact, there was no capitalism in Ancient Greece, where democracy was born. And there is no democracy in modern-day China, where capitalism is running at full speed (and the same could have been said for many Latin-American countries in the $20^{\text {th }}$ Century, when dictatorships or U.S. puppet governments profitably cohabited with capitalism). The positive association between democracy and capitalism (i.e., the idea that democracy cannot blossom without capitalism) is mostly a matter of faith. It is constructed only in our minds (as are most things). In fact, as in the case we have just tried to make, and as many prominent columnists usually argue in times of financial and economic turbulence, democracy and capitalism are in conflict more often than not. To reduce or remove this struggle, one leading idea has been suggested by the proponents of saving journalism from capitalist trends: to turn media structures into low or non-profit organizations.

The idea of the media as non-profit institutions is not at all new, but this should not diminish its value, since it has never been truly discussed or taken into account as a serious alternative to corporate and public media. Commercial interests have succeed in attracting most of the government action in democratic countries, while public broadcasting has been regarded in western Europe as the place where the commoditization of private media could be counterbalanced. Private non-profit initiatives, although already in existence, have always been residual and regarded as irrelevant. Today, several significant voices are claiming that low or non-profit media can indeed play a key role in the present crisis and in the compulsory restructuring of the media sector. Their main proposals are the conversion of old commercial media into low or non-profit media, the advancement of extant non-profit media, the creation of low or non-profit news start-ups, the formation of new shared-user non-profit networks and the recognition of universities as the core news organizations of the future.

\footnotetext{
${ }^{8}$ Actually, there is a non-profit organization that has been arguing the same in Europe for the last 12 years: The Association pour la Taxation des Transactions pour l'Aide aux Citoyens (Association for the Taxation of Financial Transactions for the Aid of Citizens, ATTAC). ATTAC promotes a tax on foreign exchange transactions, the so-called Tobin Tax, at the practical level, and a dismantling of all speculative financial activity at the general level.
} 


\subsection{Converting Old Commercial Media}

According to McChesney and Nichols ${ }^{9}$, shifting old commercial media from high-profit to low or non-profit ownership could be not only a mechanism for keeping U.S. journalism alive but also a safe way for them to transit from old media to new. Instead of directly bailing out commercial news media, these authors suggest that they must first become non-profit organizations in order to be eligible to receive public help. To get that, legislation should be crafted to expedite the transition of failing daily news media into solvent non-profit or low-profit entities (McChesney \& Nichols, 2010).

Steve Coll $^{10}$, former managing editor of the Washington Post, also proposed that the U.S. Congress make it easier for news organizations to refound themselves on a non-profit basis (Coll, 2009).

These authors are mainly referring to U.S. newspapers, but the argument can just as easily be made for the whole Western media world. Europe, in particular, is the continent that traditionally has the highest amount of public subsidies for private commercial media. Press subsidies are, for instance, a common trait of European State policies (Fernández Alonso et al., 2006), with countries like France that stand out because of their large amount of direct subsidies being invested traditionally - and increasingly in recent years - in private media to help save press journalism from bankruptcy.

\subsection{Promoting Old Non-Profit Media}

While the most noteworthy alternative proposal in the U.S. is the transformation of old commercial media into low or non-profit media, on the European continent the alternative is focused on old non-profit media. In Europe, the private non-profit sector has traditionally received far less funding and is less professionalized than in the U.S. - mainly because of the practically non-existent philanthropic tradition regarding news organizations, the existence of strong European public broadcasting systems and the major active support to the private commercial media industry given by the European Union and by European governments. However, or precisely because of this, there is now a growing community of European scholars, researchers and practitioners that stresses its support for the old non-profit media field as a way of enhancing democracy. In spite of their differences and their mostly theoretical and sociological perspectives, a call is clearly made for more regulation to protect the 'third media' sector (the non-profit broadcasting media alternative to public and commercial media).

Laura Bergés ${ }^{11}$ states that this lack of regulation makes the promotion of pluralism and diversity in the media by European authorities something more rhetorical than real, and something that better fits the description of neoliberal globalization than the promises of the Information Society project advocated by the European Union in 2004 (Bergés, 2010). The historical absence of legislation that Bergés describes concerning the third media sector in Spain is common to the West and reflects the Community Media Forum Europe's ${ }^{12}$ main proposal: that politicians should acknowledge the true existence of the third media sector, its democratic potential and rights, and should promote such media instead of regulating as if they were non existent. In other words, they argue that European non-profit media should be taken into account in national regulations alongside the public and the commercial media sectors.

\footnotetext{
${ }^{9}$ Robert W. McChesney is a Gutgsell Endowed Professor in the Department of Communication at the University of Illinois at Urbana-Champaign, U.S., and President and co-founder of Free Press, a national media reform organization. John Nichols is an American journalist and author.

${ }^{10}$ Steve Coll is president of the New America Foundation, U.S., and a staff writer at The New Yorker magazine. He is a former editor of The Washington Post.

${ }^{11}$ Laura Bergés is an associate lecturer in the Media, Communication and Culture Department at the Autonomous University of Barcelona, Spain.

${ }^{12}$ The Community Media Forum Europe (CMFE) is a common platform for networks, national federations and projects active in the community media sector. It was created in 2004.
} 
In northern Europe, Bart Cammaerts ${ }^{13}$ recently denounced how community radio stations in the West are often forced to operate on the fringes due to this lack of proper regulation, and he calls for Western media policies to "urgently" create "an enabling environment for participatory community radio initiatives" (Cammaerts, 2009). Like Bergers, Cammaerts explains that this situation is due to the fact that community radio movements have little lobbying power and are usually positioned as rogue and unprofessional actors within the broadcasting community. This demand for promotion and legal protection has also driven recent doctoral dissertations on the third media sector (see, for instance, Sáez, 2008, or Hadl, 2006).

Furthermore, and as a specific European trait, the call for more protective regulation has also reached the political sphere, although only at a symbolic level. In 2008, the least market-driven political institution of the European Union, the European Parliament, adopted a resolution on community media in Europe, in which the promotion and protection of non-profit media were strongly called for and their positive democratic role openly acknowledged (European Parliament, 2008). A year later, the Council of Europe, one of the oldest international organizations working towards European integration, adopted a similar resolution asking European countries to protect what was labelled as a key tool for social cohesion (Council of Europe, 2009). Although none of these resolutions are compulsory regulations, both institutions have a strong reputation in Europe, and the European Parliament is regarded as the institution closest to citizens.

The economic crisis has also recently encouraged European scholars in various fields to publicly support the wider field called 'social economy' through an open letter sent to the European Commission. The call to promote the social economy - where the non-profit media sector can be situated - is made in the "need to move beyond the paradigm that sees private for-profit firms and public institutions as the only relevant actors and move towards a pluralist view that recognizes the varied roles that different forms of enterprise can play with respect to our collective social and economic goals" (Euricse, 2010). Again, the criticism focuses on the absence of a legal framework regulating these organizations, while a strong argument is made for the values and long-term benefits that this third media sector entails.

\subsection{Creating Non-Profit News Start-Ups}

Converting old commercial media into low or non-profit organizations and promoting old non-profit media is only half the story. Several authors also argue that new media start-ups should also be non-profit organizations for the purposes of paving the way towards saving journalism. Of course, that has already started to happen and, according to these authors, this is a real opportunity for professional independent journalism to blossom. McChesney and Nichols, for instance, believe that the 2008-2010 crisis led to the acknowledgment that the Internet will not lead to the rebirth of journalism. However, as digital non-profit news media are much easier and cheaper to sustain, they represent an ideal scenario. Actually, the two American scholars suggest that AmeriCorps ${ }^{14}$ should put their thousands of young volunteers to work as journalists on start-up digital publications covering neglected communities nationwide (McChesney \& Nichols, 2010).

Also in the U.S., Leonard Downie Jr and Michael Schudson ${ }^{15}$ are among the many who make a case for expediting the conversion to low or non-profit news media organizations. In particular, they ask for the process to be made easier and more flexible, even in cases where a mix of financial support (including commercial sponsorship and advertising) is in use (Downie \& Schudson, 2009). The belief that non-profit media have the right to be funded by advertising and sponsorship, when

\footnotetext{
${ }^{13}$ Bart Cammaerts is a lecturer in the Department of Media and Communications at the London School of Economics and Political Science (LSE).

${ }^{14}$ AmeriCorps is a U.S. Federal Government programme created by the National and Community Service Trust Act of 1993. Since then, AmeriCorps has worked as a division of the Corporation for National and Community Service (CNMS), a government agency that acts much like a foundation, and it is the nation's largest grant maker supporting service and volunteering.

${ }^{15}$ Michael Schudson is a professor of communication at the Columbia University Graduate School of Journalism. Leonard Downie, former executive editor of The Washington Post, is the Weil Family Professor of Journalism at the Cronkite School at Arizona State University.
} 
public service news reporting is guaranteed, is also a claim in Europe. In Spain, for instance, the recently passed General Broadcasting Act 2010 has been heavily criticised by the association ULEPICC-España ${ }^{16}$, among others, for its treatment of non-profit media. This Spanish association of scholars thinks the Act is sentencing non-profit media to poverty, since it severely restricts their annual budget and explicitly prohibits advertising and sponsorship (ULEPICC-España, 2010).

The idea of a State taking on a commitment of promoting and helping the creation of non-profit media is an old demand in Latin America as well, reinforced in 2000 by the "Declaration of Principles on Freedom of Expression" issued by the Inter-American Commission on Human Rights. The declaration states that "The concession of radio and television broadcast frequencies should take into account democratic criteria that provide equal opportunity of access for all individuals" (Principle 12). That text inspired the wave of progressive regulations regarding the media recently developed in several countries of the Latin-American region according to Cabral (2010) - we shall look at these later.

In this context, in recent decades several authors around the world have been making a case for building a three-pillar media system that includes, on equal terms, the non-profit sector alongside the private and State ones. They have been arguing in favour of non-profit organizations, not as a specific answer to a specific crisis in journalism, but as a way of ensuring fundamental rights and consolidating democracy. In this sense, we can consider them as promoters of a global answer to the permanent crisis experienced by journalism due to its corporatization and financialization. This paper is neither the place for, nor does it have the purpose of, providing a summary of their work progress. However, their key role must be recognized in the shaping and building of a global awareness of the alternative media reality. Together, they have made a strong case for the alternative media space to survive and challenge hegemony. ${ }^{17}$

\subsection{Devising New Shared-User Non-Profit Networks}

Although the Internet is not the solution to our problems, but rather another platform on its way towards being completely privatised, walled off and exploited for profit, some technological approaches based on the digital sphere are providing ideas free from this capitalist trend.

This might be the case of the Information Valet Economy project promoted by Bill Densmore ${ }^{18}$ for the Donald W. Reynolds Journalism Institute (Densmore, 2009). The Information Valet Economy proposal is based on sustaining news and information through a shared-user network founded on a system devised never to be owned or controlled by either the government or a dominant private, for-profit entity. On the contrary, the idea is to create a collaboratively owned news service to replace old newspapers. Such a system would provide a new business model for media capable of channelling money into the network as a "24/7, platform-agnostic nerve centre that finds, organizes, shares and makes sense of information from a vast array of paid, volunteer, independent and partisan sources". Although not completely devoid of a for-profit aim, Densmore's proposal makes a considerable leap with regard to the news organization; it promotes a system that rethinks the notion of the news as a product, and conversely regards it as a collaborative service within a non-profit system.

\footnotetext{
${ }^{16}$ ULEPICC-España is the Spanish branch of ULEPICC, the Association of scholars and researchers of political economy of communications and culture from Spanish speaking and Latin-American countries.

${ }^{17}$ In addition to the classic works in this field (Downing, 1984, 2001 and 2003; Rodríguez, 2001; Atton, 2002; Couldry \& Curran (eds.), 2003, etc.) some more recent studies include those by: Rennie, 2006; Fuller(ed.), 2007; Cammaerts \& Carpentier (eds.), 2007; Carpentier, 2008; Guides, Cammaerts \& Carpentier, 2008; Cammaerts, 2008; Atton \& Hamilton, 2008; Moraes, 2009; Atkinson, 2010; and Howley (ed.), 2010.

${ }^{18}$ Bill Densmore is director/editor of the Media Giraffe Project at the University of Massachusetts-Amherst, and the New England News Forum. In the 2008/2009 academic year, Densmore served as a Reynolds Fellow at the University of Missouri working on The Information Valet Project.
} 


\subsection{Universities as Core News Organizations}

Finally, there are those who state that in order for independent journalism to flourish on a scale capable of attaining global media coverage, non-profit is not enough. There must be an institution behind it to support the whole thing. And this institution must have "a culture of journalism as a profession". That is, at least, the argument put forward by Lee C. Bollinger (2010), president of Columbia University ${ }^{19}$, who calls for universities, already non-profit institutions, to become the core news organizations of the future.

Bollinger's proposal is based on the magnitude that is needed: "Some of the organizations that make up the press must have sufficient scale to have serious newsgathering ability [...]. The simple fact is that there are some things we want that only big organizations can provide" (Bollinger, 2010, p. 110). Universities "may assume responsibility to become 'teaching news organizations' in the way medical schools run teaching hospitals" (Bollinger, 2010, p. 111).

The argument claiming that universities should be core centres to encourage, promote and produce accountable and professional journalism is also currently supported by Downie and Schudson, who state that:

Universities, both public and private, should become ongoing sources of local, state, specialized subject, and accountability news reporting as part of their education missions. They should operate their own news organizations, host platforms for other non-profit news and investigative reporting organizations, provide faculty positions for active individual journalists, and be laboratories for digital innovation in the gathering and sharing of news and information.

(Downie \& Schudson, 2009)

In August 2010, the North American Association for Education in Journalism and Mass Communication (AEJMC) organised a workshop to discuss the challenges and opportunities of Journalism Schools as news providers. The seminar, a preconference event held in Denver, U.S., was motivated by the idea that, as newspapers shrink, journalism schools are filling gaps in news coverage through Pro-Am journalism.

However, it must be stressed that this proposal entails an Anglo-Saxon approach, in which public universities are mainly organized as private charities - while in continental Europe not everybody would agree on considering universities as non-profit institutions, since the public ones are public educational organizations, thus belonging to the public sector.

\section{Sources of Funding for Non-Profit News Organizations}

Working towards non-profit organizations is, of course, not the whole solution, since non-profit media still need resources to produce news and to become a way of making a living for the people engaged in them. Ideas suggested here vary considerably and, although most of the proponents agree that a mix of them would provide the best solution, not everybody agrees with everything. The main and best-grounded proposals include government funding, national funding, philanthropy, public (citizen) funding and public-interest commercial funding.

\subsection{Government Funding}

Publicly subsidizing private non-profit media is the central argument of McChesney \& Nichols (2010) supported by others, as is the case of William F. Baker ${ }^{20}$ (2009). According to McChesney \& Nichols, "having anything remotely close to a satisfactory level of journalism will require a large public subsidy" (McChesney \& Nichols, 2010, p. 159). Although these authors believe in the basic right of anyone to start a media business or enterprise of any kind, they also think that evidence suggests that the "corporate, advertising-supported, profit-driven model for journalism is no longer

\footnotetext{
${ }^{19}$ Lee C. Bollinger is the $19^{\text {th }}$ president of Columbia University. Formerly the president of the University of Michigan, he is a noted legal scholar of the First Amendment and freedom of speech.

${ }^{20}$ William F. Baker is president emeritus of WNET, the largest PBS station in the U.S., and a university professor at Fordham University in New York City.
} 
viable" (2010, p. 162) and that subsidizing strong journalism must be done and can be done mainly, if not only, for the benefit of non-profit organizations. The McChesney \& Nichols argument is especially strong in their criticism of two things. First, they denounce the gurus, executives and politicians that continue to fantasize about the Internet and the new financially viable model of journalism that will pop-up sooner or later as a result of digital technologies. Second, they make a very strong point in reminding us that, in the history of the U.S., there are plenty of examples of media subsidies, in spite of what the majority of U.S. citizens might think.

Professor Todd Gitlin ${ }^{21}$ has added that public subsidies can be applied with all the necessary guarantees: "If there were a national endowment that poured money into serious reporting via local boards dominated by professional (platform-neutral) journalists, it could do a great deal to wall off the journalists from the smothering embrace of the state" (Gitlin, 2009). The alternative is not feasible:

What I do know is that journalism is too important to be left to those business interests. Leaving it to the myopic, inept, greedy, unlucky, and floundering managers of the nation's newspapers to rescue journalism on their own would be like leaving it to the investment wizards at the American International Group (AIG), Citibank, and Goldman Sachs, to create a workable, just global credit system on the strength of their good will, their hard-earned knowledge, and their fidelity to the public good. (Gitlin, 2009)

Outside the academic community, the application of public subsidies also receives support from the U.S. journalist and member of the New American Foundation Steve Coll, who asked the U.S. Congress to reform and strengthen the federal grant system in order to substantially increase its budget and include journalism as part of its mission: "To enhance independent, nonpartisan, evidencebased reporting about public institutions, public issues, and international affairs" (Coll, 2009).

Albeit with less visibility, public subsidies have been called for in Europe too, in order to keep private investigative reporting alive, as was the case of Peter Humphreys' proposal in a conference organized by The Netherlands Press Fund ${ }^{22}$ (Humphreys, 2007).

Additionally, in the U.S., some voices have openly demanded the full funding of public media, an approach similar to the one taken by European countries to their public broadcasting systems. Professor Baker makes his argument against the common fears and clichés of American society towards public media: "There are numerous democratic nations with public broadcasting systems that are both well funded by their central government and also well shielded from its political influence". Baker illustrates this in figures: federal U.S. support for public broadcasting is 12 times smaller than the support received by the British BBC (although the BBC is serving a nation with one fifth of the U.S. population) or 23 times smaller than the support received by German public broadcasters (a nation with one third of the U.S. population). According to the former president of New York's PBS station, pumping more money into the public media infrastructure could fortify the eroding foundation of print journalism on which the rest of news media depend in the U.S., because that could mean jobs for the rapidly growing number of unemployed print journalists (Baker, 2009).

Coll also asked for a reform and strengthening of the Corporation for Public Broadcasting in the U.S. to ensure that its investments in public broadcasting stations more fully and successfully address the losses in independent reporting on public institutions and international affairs experienced by for-profit newspapers and broadcasters (Coll, 2009). The permanent criticism and private lobbying against public media budgets within Europe should be confronted with those arguments.

\subsection{National Funding}

In accordance with the above, Downie and Schudson suggest a specific way of publicly subsidizing local media: charging the bill to the biggest commercial players. In particular, they ask for a national

\footnotetext{
${ }^{21}$ Todd Gitlin is a professor of journalism and sociology and chair of the Ph. D. program in Communications at Columbia University.

${ }^{22}$ Peter Humphreys is a professor at the School of Social Sciences at the University of Manchester, United Kingdom.
} 
fund for local news to be created with money that the Federal Communications Commission (FCC) already collects from, or could impose on, telecom users, television and radio broadcast licensees or Internet service providers, which would be administered in open competition through State Local News Fund councils.

The idea is aimed at solving the particular failure of local news markets. According to both authors, the FCC should direct some of the money collected in that manner to "finance a Fund for Local News that would make grants for advances in local news reporting and innovative ways to support it" (Downie \& Schudson, 2009). These authors' proposal even includes the idea that commercial broadcasters who no longer cover local news or do not otherwise satisfy unenforced publicservice requirements could also pay into such a fund instead.

Steve Coll also supports this idea of private commercial broadcasters and licensees contributing to a fund that would be used to finance reporting on public institutions and public issues (Coll, 2009).

In all cases, although this suggestion is not specifically devised for non-profit media, it seems obvious that such a fund, with commercial broadcasters mainly ruled out because of their inability to provide local news, could be of great benefit to low or non-profit organizations. ${ }^{23}$

\subsection{Philanthropy}

Philanthropy is a well-established tradition in Anglo-Saxon countries, and remarkably so in the U.S. Although regarded mainly as a form of individual-egocentric charity in the continental-European approach, which has devised a collective (State) protection system stronger than the one in the U.S., there is also a growing trend towards philanthropy in Europe - and, of course, it is a common reality in countries influenced by the U.S. (at present or in the past), and in countries with major social and economic inequalities. Regardless of the unfair nature of a social system built upon billionaires donating funds to help promote minimally attended or wholly unattended common social areas (especially considering the unethical origins of most big fortunes), the fact is that billionaires do exist. And, although the point would be to keep societies from producing such inequalities, already existing billionaires can be of much use in funding unattended social areas. At least this is what many proponents of philanthropy think nowadays, although not all of them share the idea that individual philanthropy should eventually be replaced by collective (State) aid.

The above explains why the main proponents of philanthropy as a way of saving journalism, or at least helping to do so, are in the U.S. Downie and Schudson make a strong argument for it, for instance. They think that philanthropists, foundations and community foundations should substantially increase their support for news organizations "that have demonstrated a substantial commitment to public affairs and accountability reporting". They base their suggestion on the fact that philanthropy has been essential in the U.S. for educational, research, cultural and religious institutions, as well as health and social services, among others. However, with the exception of public radio and television, philanthropy has played a very small role in supporting news reporting, because most of it has been subsidized by advertising (Downie \& Schudson, 2009).

Bollinger also asks for "people of enormous wealth" to "take the press on as philanthropic activities"' (Bollinger, 2010, p. 111), which is congruent with the argument of converting universities into core news institutions - insofar as some U.S. universities are already largely funded by philanthropy (as is increasingly occurring in the rest of the world as the culture of philanthropy spreads as a common trait of financial capitalism).

Although not as the only source of funding, Baker also argues that private philanthropy can be, alongside government support, the best answer to the question of how to save journalism. The entrepreneurial initiatives already started up based on philanthropic funds provide the main body of evidence for this, according to this scholar and former journalist (Baker, 2009).

${ }^{23}$ In Europe, the French and Spanish governments have recently set up similar funds. But this mechanism (which is currently subject to review) is not aimed at funding non-profit private media but rather at securing alternative sources of revenue (other than advertising) for the French and Spanish public broadcasting systems. Thus, it has been seen as another success of private media lobbying against public media systems. 
However, the most outstanding proponent of philanthropy as a way of saving journalism is Pablo Eisenberg $^{24}$. The French scholar, who grew up in the U.S., argues that the current crisis is killing investigative reporting and that only private non-profit newspapers would be able to reverse this trend. For them to exist, the solution would be for individual philanthropists or foundations to buy "first-class" private commercial newspapers currently in trouble. The aim is clearly to protect investigative and quality journalism from "avaricious owners" or from Wall Street, thus isolating them from market influences. This is the only way, according to the Georgetown scholar, to keep a watchdog journalistic practice over the public sector, as newspapers are the only serious mechanism that we have to keep an eye on the public sector. He explains how this has to be done:

[...] it would be important that the informative and business roles be kept separate. And also that the newspaper should have an independent governing board that cannot be controlled by the new owners, whether it be a foundation, George Soros or even Arthur Schulzberger, of the New York Times. The tradition of good newspapers mandates the establishment of a wall between the informative function and the business function, something terribly important for their subsistence. (Eisenberg, 2009a)

Furthermore, Eisenberg argues that it is the non-profit sector that actually needs newspapers rather than the other way around. For it has been the media, notably print journalism, that has assumed responsibility for keeping the non-profit sector publicly accountable over the last twenty years. Thus, the disappearance of independent newspapers would be a major threat to the accountability of the whole U.S. non-profit sector (Eisenberg, 2009b).

In the U.S., charitable foundations have already started moving in to fill gaps left by for-profit organizations. The training of newspaper personnel and even paying for news is a task of federally recognized charitable organizations. However, the scholars cited above call for a greater engagement of the field of philanthropy beyond experimental approaches to news coverage or the provision of the means for investigative work not covered in the traditional newsroom budget.

\subsection{Public (Citizen) Funding}

"Supported by viewers like you" has been a slogan of the U.S. PBS network for a long time. As professor Baker reminds us, with very few exceptions, "foundation and corporate giving has never provided as much to public television as small individual pledges" since "for more than fifty years the American people have shown, through their generous donations, that they support the idea and the reality of public media" (Baker, 2009). That has always been regarded as evidence of the true possibility of counting on people, on citizens, to support news organizations, although it can never be the sole source of funding. Nevertheless, many believe that citizen donations can be a key element of the mix that any non-profit news organization will require to funnel resources into new public-interest journalism.

Actually, some non-profit news organizations are already successfully using micropayments collected from the public to fund local investigative and enterprise reporting. This is the case of Spot.us, a project launched in San Francisco in partnership with the Annenberg School of Communication (University of Southern California). According to Spot.us, in only one year they succeeded in proposing, funding and writing about 30 articles, the highest profile one for The New York Times. In this case, rather than backing a news organization, the public is asked to consider funding individual local stories.

\footnotetext{
${ }^{24}$ Pablo Einseberg is a senior fellow at the Center for Public \& Nonprofit Leadership at Georgetown University. It is noteworthy that, prior to this position, Eisenberg served for 23 years as executive director of the Center for Community Change, a U.S. national technical assistance and advocacy organization working with low-income constituencies nationwide. He has contributed to the U.S. national discourse on government accountability and reform, the role of philanthropy, and the achievements and problems of the non-profit sector.
} 


\subsection{As Usual but With Public-Interest Aims}

Finally, most of the proponents of non-profit journalism do not renounce traditional resources, although they do introduce some important nuances. For instance, traditional advertising is still accepted by many as a funding option, but under no circumstances as the only possibility (whether simply because advertising will no longer be able to support journalism on its own, or because it is not acceptable as the sole source of funding due to the pressures that it places on public-interest journalism).

Direct subscriptions are, of course, another traditional way of funding that should not be excluded from the mix of resources that could fund a non-profit news organization.

However, the non-profit proponents add two other sources to those mentioned above. First, accountable advertising, which seems far better suited to the public interest of non-profit media than commercial advertising. This refers to the advertising of non-commercial products or responsible advertising (although reaching a consensus on what 'responsible' means would seem to be a difficult task). Second, syndicating and selling stories to commercial news organizations is something that non-profit news producers have started to implement.

\section{U.S. and Latin-American Initiatives}

In this section we shall look at initiatives recently implemented in the U.S. and Latin America. The U.S. case is underscored because it is considered a remarkable example, especially as these initiatives have arisen in what for many is considered to be the paradigm of an individualistic freemarket ideal. The Latin-American case is interesting because, besides a long tradition in community media, some political decision makers have started to actively use regulation to protect low or non-profit media models, or to help definancialize media models.

\subsection{U.S.}

Europe has traditionally been the point of reference in terms of public media development. For progressive people in America, quality, public European-media models, such as the BBC, are usually regarded as an inspiration - mainly in terms of funding. However, and paradoxically, the weakness of the American public sector has allowed a private non-profit media sector to blossom in North America and in South America that is without parallel in Europe. This is probably why some of the best examples of non-profit media models can now be found there. It is in the North, and mainly in the U.S., where private non-profit news organizations have always been strongest and, undoubtedly, the place where private non-profit media have flourished the most since the Internet boom, largely due to individual and foundation donations. Although most of the organizations often implement more than one working model, four main types of private non-profit journalism endeavour could be identified in 2010 in the U.S. ${ }^{25}$ :

\subsubsection{Centres for Training and Promoting/Funding Independent Reporting}

The Knight Foundation is probably the largest organization of this type. Focused on training and education in the digital era, it is one of the largest funders through its journalism grant programme. The Knight Foundation is not the only foundation in the U.S. funding journalism ${ }^{26}$, but it is the leading one. Created in 1950, in 2009 more than $\$ 140$ million were approved in new grants and the foundation had approved a total of $\$ 1$ billion in grants by mid-2006. As it is explains on its website, for the first 10 years (1950-1960), the foundation's assets came from contributions from the Akron Beacon Journal and The Miami Herald, and personal gifts from Jack and Jim Knight. Other Knight newspapers began to contribute small amounts in the early 1960s. However, newspaper contribu-

\footnotetext{
${ }^{25}$ For a list of U.S. non-profit news endeavours, we recommend the Hauser Center for Nonprofit Organizations database (Harvard University): http://www.hks.harvard.edu/hauser/engage/artsculturemedia/nonprofit-news-organizations/index.html

${ }^{26}$ Other U.S. journalism funders are the Ford Foundation, the Ethics and Excellence in Journalism Foundation, McCormick Tribune Foundation, Sripps Howard Foundation, Gannet Foundation, Hearst Foundation and the Open Society Institute.
} 
tions stopped in 1965 with the foundation's first major infusion of assets - a bequest of 180,000 shares of Knight Newspapers stock from the Knights' mother, Clara I. Knight, who died that November. Over the next few years, a limited number of cultural and educational institutions in Akron, Miami, Charlotte and Detroit - cities where the Knights owned newspapers - were added to the foundation's list of grant recipients. A turning point came in 1972 when trustees authorized the sale of Clara Knight's stock, raising more than $\$ 21$ million. The contribution increased the foundation's assets to more than $\$ 24$ million and initiated an expanded grant programme focused on the growing number of cities where the Knights published newspapers. In 1981, Jack Knight died leaving the bulk of his estate to the Knight Foundation. The task of settling his estate required five years. When the final transfer of funds to the foundation occurred in 1986, the distribution from the bequest totalled $\$ 428$ million, making the Knight Foundation the $21^{\text {st }}$ largest U.S. foundation based on asset size. In 1991, it was Jim Knight who died, leaving what became a $\$ 200$ million bequest to the foundation.

\subsubsection{News Organizations that Produce to Sell to Third Parties}

Associated Press is the oldest example, while a newer one is the Under-Told Stories Project. The Under-Told Stories Project is a collaborative project involving international journalism and teaching. They engage students from Saint John's University and the College of Saint Benedict in courses, internships and mentoring opportunities, providing a forum for critical reflection on the world's under-reported news stories and hands-on skills in media production. The Under-Told Stories Project is devoted to increasing public awareness of under-reported international topics and is partly funded by the sale of its stories to public television and radio stations.

\subsubsection{Non-Profit Information Newsrooms}

The veterans FreePress (since 1987) or Democracy Now! (since 1996) are good examples here. FreePress, although mainly a media reform platform, produces a daily newsletter on media reform headlines while Democracy Now! is, at it defines itself, "a daily TV/radio news program airing on over 800 stations, pioneering the largest community media collaboration in the U.S.". The Free Press and the Free Press Action Fund, their advocacy arm, are non-profit organizations that rely on donations from their members. Democracy Now! is an organization funded entirely through individual donations and grants from foundations (no corporate underwriting or government support).

\subsubsection{Non-Profit Investigative Reporting Newsrooms}

The Pulitzer Prize winning ProPublica is probably the best example here. Specialized in hardhitting investigative journalism, ProPublica's investigations are conducted by its staff of full-time investigative reporters and the resulting stories are given away to news 'partners' for publication or broadcast. ProPublica's efforts to maximize the impact of its journalism in the public interest are clear:

Each story we publish is distributed in a manner designed to maximize its impact. Many of our 'deep dive' stories are offered exclusively to a traditional news organization, free of charge, for publication or broadcast. We published 138 such stories in 2009 with 38 different partners. Each story is also published on this site. (ProPublica Website on 24 May 2010)

ProPublica is the creation of Herbert and Marion Sandler, the former chief executives of the Golden West Financial Corporation, who have committed $\$ 10$ million a year to the project. The Sandler Foundation has made a major, multi-year commitment to fund ProPublica, but other philanthropic contributions have been received as well.

The Center for Public Integrity and the Center for Investigative Reporting are other examples of non-profit organizations devoted to investigative independent reporting. The Center for Public Integrity conducts investigative projects that explore the interaction between private interests and government officials and its effect on public policy involving matters of public integrity. It is sup- 
ported by foundations and individuals and does not accept contributions from labour unions, governments or anonymous donors. On the other hand, founded in 1977, the Center for Investigative Reporting is the nation's oldest non-profit investigative news organization, according to its website, and it is supported by private foundations and individuals donations.

\subsection{Latin America}

Over the last decade, Latin America has experienced a quantum leap in its political institutions, with a majority of newly elected governments turning towards independence from the U.S. and with much more concern about social protection. In this context, some countries have passed new communications Acts that take into account non-profit media in unprecedented ways. It is worth noting that Latin-American countries, with very weak public media systems in terms of democratic values in the past, have a long tradition in the non-profit area, although mainly with a proselytist aim (up to now, religious - although mainly the progressive sectors of the Catholic Church - and politically supported non-profit news organizations were the main type of non-profit media). However, recent regulation goes further in this area.

\subsubsection{Venezuela}

Bolivarian Venezuela has been largely and publicly subsidizing non-profit local and popular news organizations since Hugo Chávez was elected for the first time in 1999, as a way of counteracting the political role of commercial media against the three-times elected President. Although a major effort in public media has been made (to increase their number and influence), the political attempt made by President Chávez to build a national public system of popular and alternative communication is possibly even greater (Mújica, 2009). Critics argue that this alternative system cannot really be an alternative since it is the State that is almost directly building it. However, defenders argue this is not preventing community media from having an alternative profile since the Venezuelan State is representing the popular community view and the alternative is much needed against the all-powerful commercial media. In any case, this is a very good example of a radically different way of regulating in comparison to the U.S. or European legal frameworks - mainly concerned with the interests of their respective commercial media industries.

\subsubsection{Uruguay}

In 2007, Uruguay started the democratization and protection of community media in a ruling that has been regarded as a reference for many - the Community Radio Broadcasting Act. This Act stipulates that one third of the spectrum must be set aside for community radio broadcasting stations. It acknowledges that community radio broadcasting is the 'third broadcasting sector' and, thus, not only spectrum but also access to licences and economic resources must be guaranteed for it. Government concerns on the unacceptable market concentration levels and poor guarantees for freedom of expression were clearly the motivations behind this Act. In 2010, a broader Act concerning all broadcasting media was being prepared by the National Telecommunications Director. It is worth to noting that the 2010 government officer in charge of National Uruguayan Telecommunications was very actively involved in the World Association of Community Radio Broadcasters (AMARC) until being appointed Director of National Telecommunications. Again, regardless of the results that these media policies might achieve, we are faced with a radically different way of regulating the media system in comparison to the U.S. and Europe - whose media government secretaries and ministers usually have links with the industry.

\subsubsection{Argentina}

In Argentina, the 2009 Communications Act reserves 33\% of the planned spectrum, in all bands of audio radio and terrestrial television broadcasting and all coverage areas, for non-profit organizations. In addition, native peoples will be authorized to install and run AM and FM radio stations as 
well as free-to-air television signals, and national universities will be entitled to install and exploit radio broadcast services. Universities must dedicate relevant segments of their programming to the dissemination of scientific knowledge, university extension, and artistic and cultural creation and experimentation.

\subsubsection{Ecuador}

President Rafael Correa brought about a new Constitution in Ecuador in 2008. Inspired by the latest Venezuelan and Bolivian Constitutions, the Ecuadorian magna carta included noteworthy novelties, such as the first World Bill of Rights for Nature, which grants inalienable rights to nature, alongside radically progressive provisions for the right to life and the right to a healthy environment, as well as the precautionary principle and objective/strict liability for environmental damage. Although defined by its critics as less radical than the Venezuelan and Bolivian text, the Ecuadorian Constitution includes a unique package of provisions addressing monetary and financial policies, prohibiting financial groups and institutions from diversifying their business activities into other areas and, in particular, from owning or having shares in mass media outlets. For instance, article 312 of Constitution of Ecuador asserts that:

Financial entities or groups shall not be entitled to own permanent, total or partial shareholdings in companies whose activities are unconnected with financial activities. [...] Financial entities or groups, their legal representatives, board directors or shareholders are forbidden from holding stocks, assets or investment in social communication media. (Constitution of Ecuador)

Ending in October 2010, a period of two years had been allowed for financial entities or actors to free themselves of their stock, assets or investments of any kind in the media. After that time, media owned by financial actors could lose licences. Financial powers were struggling hard trying to get around this prohibition, showing that President Correa had cleverly targeted the core of the old global media business model with these provisions, as described by some analysts:

These groups [major media outlets owned by powerful financial groups] have been some of the most virulent critics of the new leftist governments, precisely because these governments seek to redistribute wealth, increase state regulation of business, and generally act on the principle that business has social obligations. So, in Venezuela, Argentina, Bolivia, and Ecuador, the corporately controlled media are waging propaganda wars to discredit these governments and foment opposition. In this context, Ecuador's constitution targets one of the roots of the democratic deficit in countries with highly unequal levels of income and wealth: the control of the media by powerful economic interests. (Collins, 2008)

\section{Conclusions}

In this paper, we have introduced and tried to classify the main alternative calls and initiatives recently raised or launched in U.S., Europe and Latin America that seek a real shift in order to free the media from the current model. In doing so, our ultimate goal has been to provide a view of what can be considered the most significant tide of ideas and actions to date against the corporatization and financialization of the media and journalism. It has not been our intention to provide a comprehensive catalogue of ideas and initiatives (if such a thing is possible), nor to offer an assessment of the viability or real potential to effect change of all of them (that would go far beyond the descriptive aim of this paper). Rather, the most noteworthy ideas and their proponents have been gathered here in order to highlight the existence of an alternative to mainstream claims, as well as to point out the common traits that these heterogeneous alternative claims all share. From our analyses, three main conclusions can be drawn:

First, the alternative claims introduced here provide clear answers to the questions raised at the beginning of this paper. In this sense, they all point in the same direction and could be summarised as follows: 
- We should not look for perfect forms of organizing the media business, but for the least harmful ones we could devise right now.

- We should consider what is harmful in terms of public/social interests instead of private/individual interests.

- We should avoid defining public interest in relation to business performance; we already have evidence enough to know about the harmful consequences of this recurrent relationship throughout the $20^{\text {th }}$ century.

- We should reorganize the whole industry as soon as possible in keeping with the values and ethics of global solidarity, empathy and sustainability

Second, the ideas and initiatives introduced in this paper consider a mindset shift away from the old way of thinking about non-profit and the media, where non-profit becomes a model not just for small and secondary media, but for private mainstream media as well. In the proponents' definitions of what low or non-profit means, it is significant that most of them share the same Nots when it comes to defining the new media model:

- Not for capitalist profit (not with/for speculation, capital accumulation or personal gain).

- Not with financial capital (not with leverage, financial ties, financial partners or financial aims).

- Not with commercial enslavement (not with commercial advertising as the main source of funding).

Third and finally, the differentiated approach taken by the three regions analyzed is clear to see: while the strongest non-profit private movement has arisen in the U.S. (as has the most important activist movement), governments are the most active actors in Latin America, trying to use media policies as tools for change. However, none of these things are taking place in Europe, where a historical paradox is now being experienced: the existence of strong public media systems - those taken by the U.S. and Latin-American proponents as a very positive point of reference and even as an inspiring goal in some instances - has become a huge obstacle for non-profit alternative media to get clear support in Europe.

Many questions for discussion arise from the above. The real scope of the change promoted by those proponents and the real viability of the initiatives and ideas are, of course, the first two issues that need to be dealt with (Are they radical enough? Are they feasible?). The possibility or impossibility of regarding those initiatives as exportable outside their region of origin, into other cultural and political contexts, is another key subject that must be considered (Are comparisons of any use? In spite of their common traits, can we really consider these proposals as a compact global shift given that they are embedded in such different contexts?). The extent of the strength of the proposals when challenged by the business-as-usual-mainstream claims is another topic for discussion (Are they able to really influence change more than mainstream gurus?).

All of these open questions, however, should not prevent us from acknowledging the relevance of the core trait shared by all the proposals gathered here: their call for a kind of journalism devoid of corporate and financial capitalism. This is why we argue that, altogether and regardless of its effects, this call can be regarded as an unprecedented ethical claim to devote journalism, once and for all, to the public interest and to the building of freedom and peace. 


\section{References}

Adam, S.G. \& Clark, R.P. (2006): Journalism. The Democratic Craft. New York: Oxford University Press.

Almiron, N. (2010). Journalism in Crisis. Corporate Media and financialization. Cresskill: Hampton Press (in press).

Almiron, N., \& Jarque, J.M. (2008). El mito digital. Barcelona: Anthropos.

Atkinson, J. D. (2010). Alternative Media and Politics of Resistance: a Communication Perspective. New York: Peter Lang.

Atton, C. (2002): Alternative Media. London: Sage.

Atton, C., \& Hamilton, J. (2008). Alternative Journalism. London: Sage.

Baker, W. F. (2009). How to Save the News. The Nation, September 23. Retrieved July 30, 2010, from http://www.thenation.com/article/how-save-news.

Becerra, M., \& Mastrini, G. (2009). Los dueños de la palabra. Buenos Aires: Prometeo.

Bergés, L. (2010). Spain: an Information Society Without Traditional Community Media? Paper presented at the IAMCR Conference 2010, Braga, Portugal, July 18-22 2010.

Bollinger, C. L. (2010). Uninhibited, Robust, and Wide-Open. A free Press For a New Century. Oxford: Oxford University Press.

Bouquillion, P. (2005). La Constitution des Pôles des Industries de la Culture et de la Communication. Entre 'Coups' Financiers et Intégration de Filiares Industrielles. Réseaux, 23(131), 111-114.

Bouquillion, P. (2008). Les Industries de la Culture et de la Communication. Les Stratégies du Capitalisme. Paris: Presses Universitaires de Grenoble.

Bouquillion, P., Miège, B., \& Pradié, C. (2003). Financiarisation des Industries de la Communication et Mutations Correlatives. In G. Tremblay (Ed.), Panam. Industries Culturelles et Dialogues des Civilisations dans les Amériques (pp. 416-433). Québec: Presses de l'Université de Laval.

Bustamante, E. (Ed.) (2003). Hacia un Nuevo Sistema Mundial de Comunicación. Barcelona: Gedisa.

Cabral, A.V. (2010). Neither Private nor State: The Idea of Public as a Communication System. Paper presented at the IAMCR Conference 2010, Braga, Portugal, July 18-22 2010.

Cammaerts, B. (2008). Internet-Mediated Participation beyond the Nation State. Manchester University Press: Transaction Books.

Cammaerts, B. (2009). Community Radio in the West: A Legacy of Struggle for Survival in a State and Capitalist Controlled Media Environment. International Communication Gazette, 71(8), 635-654.

Cammaerts, B., \& Carpentier, N. (Eds.) (2007). Reclaiming the Media: Communication Rights and Democratic Media Roles. Bristol: Intellect.

Carpentier, N. (2008). The Belly of the City. Alternative Communicative City Networks. The International Communication Gazette, 70(3-4), 237-255.

Coll, S. (2009). The Crisis in Journalism and Potential Policy Responses. Testimony before the Senate Committee on Commerce, Science and Transportation, 6 May. Retrieved July 30, 2010, from: http://www.newamerica.net/publications/resources/2009/crisis_journalism_and_potential_policy_responses.

Collins, J.N. (2008): Rafael Correa and the Struggle for a New Ecuador. Global Dialogue, 10. Retrieved $31^{\text {st }}$ December, 2010, from: http://www.worlddialogue.org/content.php?id=426.

Couldry, N., \& Curran, J. (Eds.) (2003). Contesting Media Power. Alternative Media in a Networked World. Lanham, Maryland: Rowman \& Littlefield.

Council of Europe (2009). Promoting Social Cohesion: The Role of Community Media. Report Prepared for the Council of Europe's Group of Specialists on Media Diversity (MC-S-MD). Strasbourg: Council of Europe.

Densmore, B. (2009). Building the Information Valet Economy: Sustaining News and Information Through a Shared-User Network. A research Proposal for the Donald W. Reynolds, Journalism Institute, August 2008-May-2009. Retrieved September 15, 2010, from: http://www.informationvalet.org.

Downie, L. Jr., \& Schudson, M. (2009). The Reconstruction of American Journalism. Journalism Review, October 19. Retrieved July 30, 2010, from: http://www.cjr.org/reconstruction/the_reconstruction_of_american.php?page=all.

Downing, J. (1984). Radical Media: the Political Experience of Alternative Communication. Boston: South End Press.

Downing, J. (2001). Radical Media: Rebellious Communication and Social Movements. Thousand Oaks, California: Sage.

Downing, J. (2003). Enciclopedia of Radical Media. Thousand Oaks, California: Sage.

Downing, J. (2010). NANOMEDIA: 'Community' Media, 'Network' Media, 'Social Movement' Media: Why do They Matter? and What's in a Name? Text prepared for the Conference "Mitjans comunitaris, moviments socials i xarxes", organised by the Unesco Chair in Communication InCom-UAB in collaboration with Cidob (Barcelona Center for International Affairs). Barcelona (Spain): Cidob, 15 March. Retrieved August 3, 2010, from: http://www.portalcomunicacion.com/catunesco/download/2010_Downing_Nanomedia_english.pdf.

Doyle, G. (2007). Undermining Diversity: Inaction on Media Concentrations and Pluralism at the EU. European Studies: A Journal of European Culture, History and Politics, 24, 135-156. 
Einseberg, P. (2009a). Pablo Eisenberg: "Los periódicos deben convertirse en entidades sin ánimo de lucro". ABC, November 27. Retrieved September 15, 2010, from: http://www.abc.es/20091127/medios-redes-prensa/pabloeisenberg-periodicos-deben-20091127.html.

Einseberg, P. (2009b). Why Nonprofits Need Newspapers. Carnegie Reporter, 6(1), 48-49.

Euricse (2010). Appeal to the European Commission for the Support of Cooperative and Social Enterprises: From Words to Action. European Research Institute on Cooperative and Social Enterprises, Trento July 13. Retrieved August 3 , 2010, from: http://www.euricse.eu/node/559.

European Parliament (2008). European Parliament Resolution of 25 September 2008 on Community Media in Europe (2008/2011(INI).

Fernández Alonso, I., Moragas, M., Blasco, J. J. \& Almiron, N. (2006). Press Subsidies in Europe. Barcelona: Generalitat de Catalunya, Incom-UAB.

Fuller, L. K. Ed. (2007). Community Media. International Perspectives. New York: Palgrave Macmillan

Galbraith, J. K. (1993). A short History of Financial Euphoria. New York: Penguin Books.

Garnham, N. (2000). Emancipation, the Media and Modernity: Arguments About the Media and Social Theory. London: Oxford University Press.

Gitlin, T. (2009). A Surfeit of Crises: Circulation, Revenue, Attention, Authority, and Deference. Keynote speech at "Journalism in Crisis" conference, University of Westminster, London, May 19. Retrieved July 30, 2010, from: http://www.westminsternewsonline.com/wordpress/?p=1951.

Guides, O.; Cammaerts, B., \& Carpentier, N. (2008). Understanding Alternative Media. Maidenhead: Open University Press.

Hadl, G. (2006). Theory for Civil Society Media: Lessons from the World Summit on the Information Society (WSIS). PhD Dissertation. Kyoto: Ritsumeikan University.

Howley, K. (Ed.) (2010). Understanding Community Media. London: Sage.

Humphreys, P. (2007). Government Policies for a Free and Diverse Press: Press Subsidy Modalities and Justifications. Paper presented in Press and Support in Digital Age, Conference organized by The Netherlands Press Fund, October 3-4, The Hague.

Consell De L'audiovisual De Catalunya (2005): XXV anniversary of the MacBride Report. Comuncació Internacional i Polítiques de Comunicació", a Quaderns del CAC, Barcelona: CAC i Incom-UAB Retrieved December 20, 2010, from: http://www.portalcomunicacion.com/informe_macbride/eng/home.asp.

Inter-American Commission in Human Rights (2000). Declaration of Principles on Freedom of Expression. Washington, Organization of American States. Retrieved august 2, 2010, from: http://www.cidh.org/Basicos/English/Basic21.Principles\%20Freedom\%20of\%20Expression.htm

Kovach, B., \& Rosenstiel, T. (2001). The Elements of Journalism. New York: Three Rivers Press.

Lacroix, J. G., \& Tremblay, G. (1997). The "Information Society" and Cultural Industries Theory. Toronto: Sage.

Lordon, F. (2010). ¿Y Si Se Cerrara la Bolsa?. Le Monde Diplomatique en español, April, 8-9. In French: "Et si on fermait la bourse.... Retrieved July 30, 2010, from: http://www.monde-diplomatique.fr/2010/02/LORDON/18789

McChesney, R. W. (2007). Communication Revolution. Critical Junctures and the Future of Media. New York: The New Press.

McChesney, R. W. (2008). The Political Economy of Media. Enduring Issues, emerging Dilemmas. New York: Monthly Review Press.

McChesney, R. W., \& Nichols, J. (2010). The Death and Life of American Journalism: The Media Revolution that Will begin the World Again. Philadelphia: Nation Books.

McChesney, R. W., Wood, E. M., \& Foster, J. B. (Eds.) (1998). Capitalism and the Information Age. The Political Economy of the Global Communication Revolution. New York: Monthly Review Press.

Meyer, P. (2004). The Vanishing Newspaper. Saving Journalism in the Information Age. Columbia (Missouri): University of Missouri Press.

Moraes, D. Org. (2009). A Batalha da Mídia. Río de Janeiro: Pão e Rosas.

Mosco, V. (2005). The Digital Sublime. Myth, Power, and Cyberspace. Cambridge, MA: The MIT Press.

Mújica, P. (2009): Los medios comuniarios en Venezuela. Communication presented at the $2^{\circ}$ Congreso de Investigadores venezolanos de la comunicación, organized by Invecom in 2009. Retrieved December 31, 2010, from: http://www.invecom.org/eventos/2009/pdf/mujica_p.pdf.

Picard, R. G. (2010). Search for Alternative Media Business Models Hampered by Narrow Thinking. The Media Business, April 20. Retrieved July 30, 2010, from: http://themediabusiness.blogspot.com.

Picard, R. G., \& Weezel, A. van (2009). Capital and Control: Consequences of Different Forms of Newspaper Ownership. The International Journal on Media Management, 10, 22-31.

Reig, R. (2001). El Éxtasis Cibernético. Comunicación, Democracia y Neotogalitarismo a Principios del Siglo XXI. Madrid: Ediciones Libertarias

Rennie; E. (2006). Community Media. A Global Introduction. Lanham, Maryland: Rowman \& Littlefield. 
Rodríguez, C. (2001). Fissures in the Mediascape. An International Study of Citizens' Media. Cresskill, New Jersey: Hampton Press.

Sáez, C. (2008). Tercer sector de la comunicación, Teoría y praxis de la televisión alternativa. Doctoral Dissertation. Faculty of Communication Sciences, Autonomous University of Barcelona, Spain. Retrieved 15 September, 2010, from: http://www.alterinfos.org/spip.php?article2741.

Thompson, P. (2010). Convenient Fictions? A Critical Communicative Perspective on Financial Accumulation, Autopoiesis and Crisis in the Wake of the Credit Crunch. Paper presented at the IAMCR Conference 2010, Braga, Portugal, July 18-22 2010.

ULEPICC-España (2010). Proyecto de Ley General de la Comunicación Audiovisual. Reforma y Contrarreforma en la Política de Comunicación Audiovisual del Gobierno de Rodríguez Zapatero. Statement by Unión Latina de Economía Política de la Información, la Comunicación y la cultura. Retrieved September 15, 2010, from: http:// //www.ulepicc.es/documentos/DeclaracionULEPICC.pdf

Vázquez Montalbán, M. (2007). Historia y Comunicación Social. Barcelona: Mondadori.

Winseck, D. (2010). Financialization and the 'Crisis of the Media': The Mysterious Case of the Rise and Fall of [Some] Media Conglomerates in Canada. Paper presented at the IAMCR Conference 2010, Braga, Portugal, July 18-22 2010 .

\section{About the Author}

Núria Almiron-Roig

Media lecturer and researcher in the Department of Communication at Pompeu Fabra University, Spain. A former ICT journalist, her main topics of research are media financialization, policies and political economy of communication. For further information: http://www.almiron.org. 